\title{
CORRIGENDUM
}

Genes \& Development 22: 2664-2676 (2008)

\section{Corrigendum: The histone H2B-specific ubiquitin ligase RNF20/hBRE1 acts as a putative tumor suppressor through selective regulation of gene expression}

Efrat Shema, Itay Tirosh, Yael Aylon, Jing Huang, Chaoyang Ye, Neta Moskovits, Nina Raver-Shapira, Neri Minsky, Judith Pirngruber, Gabi Tarcic, Pavla Hublarova, Lilach Moyal, Mali Gana-Weisz, Yosef Shiloh, Yossef Yarden, Steven A. Johnsen, Borivoj Vojtesek, Shelley L. Berger, and Moshe Oren

We realized that there was an unfortunate error in the legend to Figure 6 of the above-mentioned article. Consequently, while the title of the legend is correct, the subsequent experimental description does not match the title and does not describe accurately what was done in the experiment. The legend should read as follows:

Figure 6. RNF20 overexpression reduces HeLa cell migration. HeLa cells were transiently transfected with RNF20-Flag expression plasmid or empty vector (pCDNA3) as control and plated $48 \mathrm{~h}$ later in the upper compartment of a 24-well Transwell tray. Migrating cells were visualized as in Figure 5A. Representative images from three partially overlapping fields are shown for each condition.

doi: $10.1101 / \operatorname{gad} .307207 .117$ 


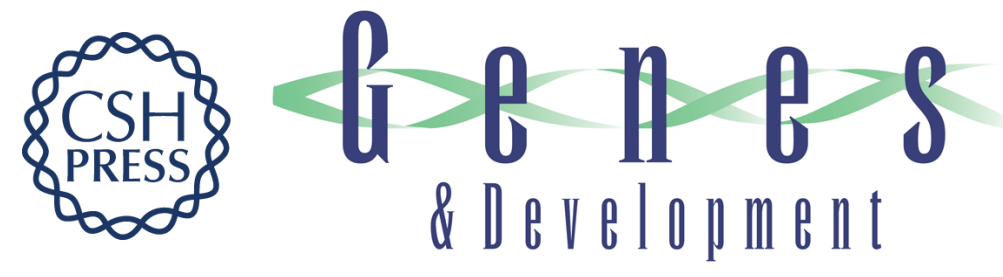

\section{Corrigendum: The histone H2B-specific ubiquitin ligase RNF20/hBRE1 acts as a putative tumor suppressor through selective regulation of gene expression}

Efrat Shema, Itay Tirosh, Yael Aylon, et al.

Genes Dev. 2017, 31:

Access the most recent version at doi:10.1101/gad.307207.117
Related Content The histone H2B-specific ubiquitin ligase RNF20/hBRE1 acts as a putative tumor suppressor through selective regulation of gene expression
Efrat Shema, Itay Tirosh, Yael Aylon, et al.
Genes Dev. October , 2008 22: 2664-2676

\section{License}

Email Alerting

Service

Receive free email alerts when new articles cite this article - sign up in the box at the top right corner of the article or click here.

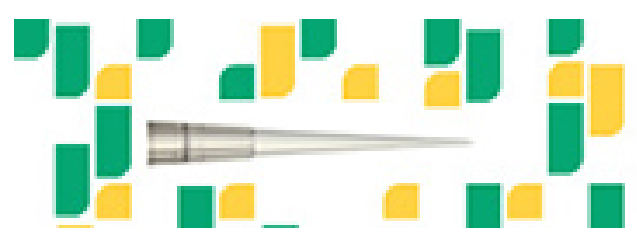

Focused on your science. 